\title{
Influence of holding between the thermal cycles on recovery in martensitic transformation temperatures in TiNi alloy
}

\author{
A. V. Sibirev ${ }^{\dagger}$, S. P. Belyaev, N. N. Resnina \\ †alekspb@list.ru \\ Saint Petersburg State University, 7/9 Universitetskaya Quay, St. Petersburg, 199034, Russia
}

\begin{abstract}
The aim of the present work was to study the features of the recovery of properties of the TiNi alloy during isothermal holding after thermal cycling in the temperature range of $200 \div 0{ }^{\circ} \mathrm{C}$. It was found that if the holding temperature was less than $200^{\circ} \mathrm{C}$, then the martensitic transformation temperatures additionally decreased in the thermal cycle after holding. If the holding temperature was equal to $200^{\circ} \mathrm{C}$, then no variation of martensitic transformation temperatures was found. If the holding temperature was higher than $200^{\circ} \mathrm{C}$, then the transformation temperatures increased in the thermal cycle after holding, hence the recovery of the properties of the alloy was observed. The higher the holding temperature, the more intensive the recovery in transformation temperatures. Since the variation in the martensitic transformation temperatures is caused by a change in the defect density, then it can be assumed that holding of the alloy at a temperature that is higher than the maximum thermal cycling temperature $\left(200^{\circ} \mathrm{C}\right)$ results in the redistribution or annihilation of dislocation structures in the alloy and this is the nature of the recovery of the martensitic transformation temperature. Thus, intermediate isothermal holding of the TiNi alloy at temperatures higher than the maximum temperature in thermal cycle allows restoring the parameters of martensitic transformations that were varied by previous thermal cycling.
\end{abstract}

Keywords: TiNi alloy, shape memory alloys, isothermal holding, martensitic transformations, thermal cycling.

УДК: 669.017 .01

\section{Влияние выдержки между термоциклами на восстановление температур мартенситных превращений в сплаве TiNi}

\author{
Сибирев А.В. ${ }^{\dagger}$, Беляев С. П., Реснина Н.Н. \\ †alekspb@list.ru
}

Санкт-Петербургский государственный университет, Университетская наб., 7/9, С.-Петербург, 199034, Россия

Целью настоящей работы было исследование особенностей восстановления свойств сплавов на основе TiNi при изотермической выдержке после термоциклирования в температурном интервале $200 \div 0^{\circ} \mathrm{C}$ в области температур мартенситных превращений. Обнаружено, что если температура выдержки не превышала $200^{\circ} \mathrm{C}$, то после выдержки температуры превращений дополнительно снижались. После выдержки при $200^{\circ} \mathrm{C}$ изменений температур мартенситных превращений не наблюдали. Если температура выдержки была более $200^{\circ} \mathrm{C}$, то в термоцикле после выдержки температуры превращения возрастали, то есть наблюдалось восстановление свойств сплава. Чем выше была температура выдержки, тем интенсивнее происходило восстановление температур превращений. Поскольку изменение температур мартенситных превращений обусловлено изменением плотности дефектов в сплаве, то можно предположить, что выдержки при температуре, превышающей максимальную температуру в термоцикле (в данном исследовании $200^{\circ} \mathrm{C}$ ), приводит к перераспределению и аннигиляции дислокаций в сплаве и это является причиной восстановления температур мартенситных превращений. Таким образом, промежуточные изотермические выдержки сплава TiNi при температурах, превышающих максимальную температуру в цикле, позволяют восстановить параметры мартенситных превращений, которые были изменены в процессе предшествующего термоциклирования.

Ключевые слова: сплав $\mathrm{TiNi}$, сплавы с эффектом памяти формы, изотермические выдержки, мартенситные превращения, термоциклирование. 


\section{Introduction}

TiNi-based shape memory alloys (SMAs) are widely used in various industries as they possess unique properties: high corrosion resistance and strength, high values of recovery stress and shape memory effects $[1,2]$. One of the application fields for SMAs is a linear actuator or heat engine working elements. To ensure a stable operation of the SMA elements in these applications, the alloys that undergo martensitic transformation at ambient temperatures $\left(20-120^{\circ} \mathrm{C}\right)$ and exhibit stable properties during thermal cycling, should be used. At the same time, it is known that an increase in the numbers of thermal cycles may lead to variations in transformation temperatures $[3,4]$ and values of shape memory effects [5-7]. These variations in functional properties occur due to an increase in the density of dislocations during thermal cycling [8]. Ni-rich TiNi alloys exhibit stable properties during thermal cycling, but their martensitic transformation temperatures are lower than $0^{\circ} \mathrm{C}$, so these alloys are not suitable for the application in actuators, which must operate at ambient temperatures.

The equiatomic TiNi alloy undergoes martensitic transformations in the temperature range of $20-120^{\circ} \mathrm{C}$, but its stability during thermal cycling is poor due to the low yield stress for dislocation slip that results in the a huge increase in the dislocation density during thermal cycling, which decreases the transformation temperatures and increases the plastic irreversible strain. Thus, it is very important to develop methods to recover the properties of an equiatomic TiNi alloy during thermal cycling. Since the main reason for poor thermal cycling stability is an increase in the dislocation density, therefore, it is necessary to decrease it between thermal cycles. It is known that alloys can partially recover their properties due to annihilation and redistribution of the dislocation structure during heating or holding at high temperatures [9]. Moreover, it was shown in [10-12] that the recovery process can occur in an equiatomic TiNi alloy at temperatures close to the temperature $A_{f}$ (the finish temperature of the reverse transformation upon heating). Thus, it can be assumed that the holding of samples at high temperature between thermal cycles should lead to a decrease in the dislocation density, which increased in the previous thermal cycle. Thus, the aim of the present work was to study the influence of the holding between thermal cycles on the variation in the temperatures and sequence of martensitic transformations in the TiNi alloy.

\section{Materials and methods}

Wire samples of the the $\mathrm{Ti}_{50} \mathrm{Ni}_{50}$ alloy (with a diameter of $0.5 \mathrm{~mm}$ ) were water quenched from $700^{\circ} \mathrm{C}$ and annealed at a temperature of $500^{\circ} \mathrm{C}$ for two hours. After annealing, the alloy underwent the $\mathrm{B} 2 \rightarrow \mathrm{B} 19^{\prime}$ transformation upon cooling $\left(M_{s}=64^{\circ} \mathrm{C}\right.$ and $M_{f}=48^{\circ} \mathrm{C}$ ) and the $\mathrm{B}^{\prime} 9^{\prime} \rightarrow \mathrm{B} 2$ transformation upon heating $\left(A_{s}=84^{\circ} \mathrm{C}\right.$ and $A_{f}=98^{\circ} \mathrm{C}$ ). The samples were subjected to 20 thermal cycles in the temperature range of $0^{\circ} \mathrm{C} \div 200^{\circ} \mathrm{C}$ at a cooling/heating rate of $7^{\circ} \mathrm{C} / \mathrm{min}$. After thermal cycling, the samples were subjected to holding at a constant temperature in the temperature range of $100^{\circ} \mathrm{C} \div 300^{\circ} \mathrm{C}$ for 60 minutes. The 4 -point resistivity measurement method was used to determine the parameters of martensitic transformations during thermal cycling and after holding.

\section{Results}

Fig. 1 shows the dependences of the resistivity on the temperature obtained in the $1^{\text {st }}$ and $20^{\text {th }}$ thermal cycles in the temperature range from 200 to $0^{\circ} \mathrm{C}$. In the first thermal cycle, an anomalous decrease in the resistivity is observed during cooling and an anomalous increase on the $\rho(T)$ curve is found during heating due to the $\mathrm{B} 2 \leftrightarrow \mathrm{B} 19$ ' transformations underwent by the alloy. In the $20^{\text {th }}$ thermal cycle, a peak on the $\rho(T)$ curve is observed during cooling, and this indicates that the sequence of transformations changes from $\mathrm{B} 2 \rightarrow \mathrm{B} 19^{\prime}$ to $\mathrm{B} 2 \rightarrow \mathrm{R} \rightarrow \mathrm{B} 19^{\prime}$ that is in a good agreement with $[13,14]$. As expected, 20 thermal cycles led to a decrease in the transformation temperatures and an increase in the resistivity (the $\rho(T)$ curve shifts to higher resistivity values), both phenomena were caused by an increase in the defect density $[3,13,15,16]$. Using the $\rho(T)$ curves, the transformation temperatures were measured as the intersection of tangent lines (Fig. 1), where $T_{\mathrm{B} 2-\mathrm{R}}$ is the $\mathrm{B} 2 \rightarrow \mathrm{R}$ transformation start temperature, $M_{f}$ - the finish temperature of the forward martensitic transformation and $A_{s}, A_{f}$ - the start and the finish temperatures of the reverse martensitic transformation (in $20^{\text {th }}$ thermal cycle: $T_{\mathrm{B} 2-\mathrm{R}}=58^{\circ} \mathrm{C}, M_{f}=34^{\circ} \mathrm{C}, A_{s}=76^{\circ} \mathrm{C}, A_{f}=84^{\circ} \mathrm{C}$ ).

After thermal cycling, the samples were isothermally held at different temperatures, and then subjected to one thermal cycle to determine how the intermediate holding influenced the transformation temperatures. Fig. 2 shows the dependencies of resistivity on temperature, obtained in the $20^{\text {th }}$ thermal cycle and in the thermal cycle after isothermal holding at a temperature of $300^{\circ} \mathrm{C}$ for 60 minutes. It is seen that the

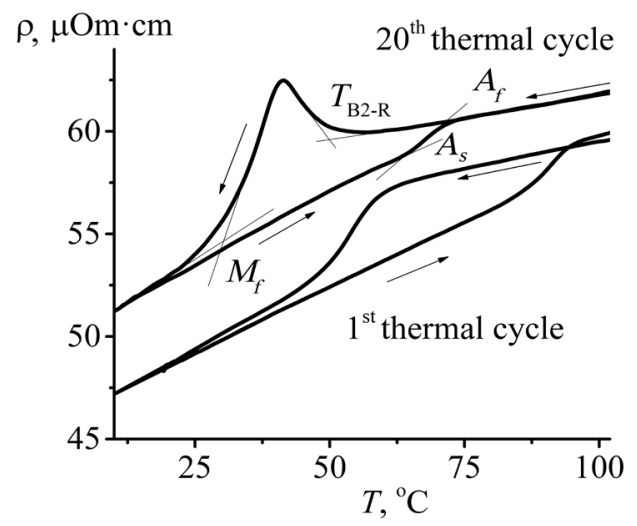

Fig. 1. Resistivity vs temperature dependences obtained in the $1^{\text {st }}$ and $20^{\text {th }}$ thermal cycles in the temperature range from 200 to $0^{\circ} \mathrm{C}$.

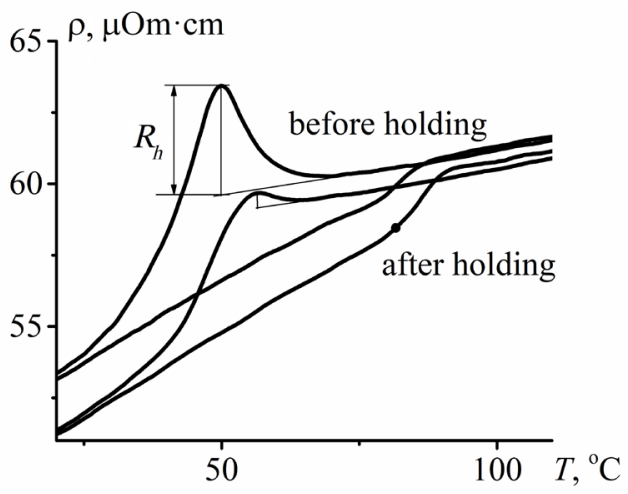

Fig. 2. Resistivity vs temperature dependences, obtained in the $20^{\text {th }}$ thermal cycle and in the thermal cycle after isothermal holding at $300^{\circ} \mathrm{C}$ for 60 minutes. 
holding results in a decrease in the resistivity value and an increase in the temperatures of the resistivity anomalies, moreover the peak that was induced by the formation of the $\mathrm{R}$ phase during the $20^{\text {th }}$ thermal cycle is significantly suppressed by holding.

Fig. 3 shows the variation in $T_{\mathrm{B} 2-\mathrm{R}}, M_{f}, A_{s}, A_{f}$ temperatures, which were measured in the thermal cycle immediately after isothermal holding at different temperatures for 60 minutes. It is seen that holding at temperatures below $200^{\circ} \mathrm{C}$ leads to an additional decrease in the transformation temperatures. If the holding temperature was equal to $200^{\circ} \mathrm{C}$, then no variation in the temperatures of martensitic transformations was observed. If the holding temperature was more than $200^{\circ} \mathrm{C}$, then the holding led to an increase in the transformation temperatures, hence a recovery of martensitic transformation temperatures was observed.

The peak on the $\rho(T)$ curve formed due to the $\mathrm{B} 2 \rightarrow \mathrm{R}$ transformation increases the resistivity and the $\mathrm{R} \rightarrow \mathrm{B} 19^{\prime}$ transformation decreases this value in the $\mathrm{TiNi}$ alloy $[3,17-19]$. It is known that in the equiatomic TiNi alloy, the R-phase is formed during cooling, since the dislocations, arising during the thermal cycle, create an internal stress that ensures the realization of forward martensitic transformation via the formation of the $\mathrm{R}$ phase [20]. Thus, it can be assumed that the volume fraction of the alloy, which undergoes the $\mathrm{B} 2 \rightarrow \mathrm{R}$ transformation, correlates with the dislocation density from one side and with the height of the resistivity peak from the other side. In this case, an increase in the height of the resistivity peak may show that the dislocation density increases, whereas a decrease in this value indicates that the dislocation density decreases. The difference in values of the peak height was calculated as $\Delta R_{h}=\left(R_{h}^{1}-R_{h}^{0}\right) / R_{h}^{0} \cdot 100 \%$, where $R_{h}^{1}$ was the peak height that was measured on the $\rho(T)$ curve obtained just after holding, and $R_{h}^{0}$ was the peak height that was measured in the $20^{\text {th }}$ thermal cycle (before holding). The dependence of $\Delta R_{h}$ on the holding temperature is shown in Fig. 4, and it is seen that the height of the resistivity peak does not change if the holding temperature is less than $200^{\circ} \mathrm{C}$, and it decreases if the holding occurs at temperatures exceeding $200^{\circ} \mathrm{C}$. After holding of the sample at a temperature of $300^{\circ} \mathrm{C}$ for 60 minutes, the resistivity peak almost disappears.

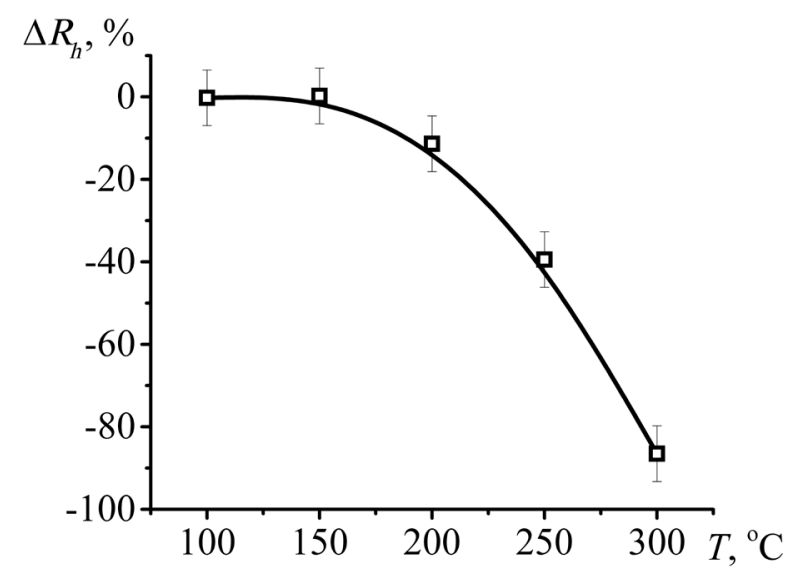

Fig. 4. Variation of the height of the resistivity peak depending on the holding temperature (60 min).
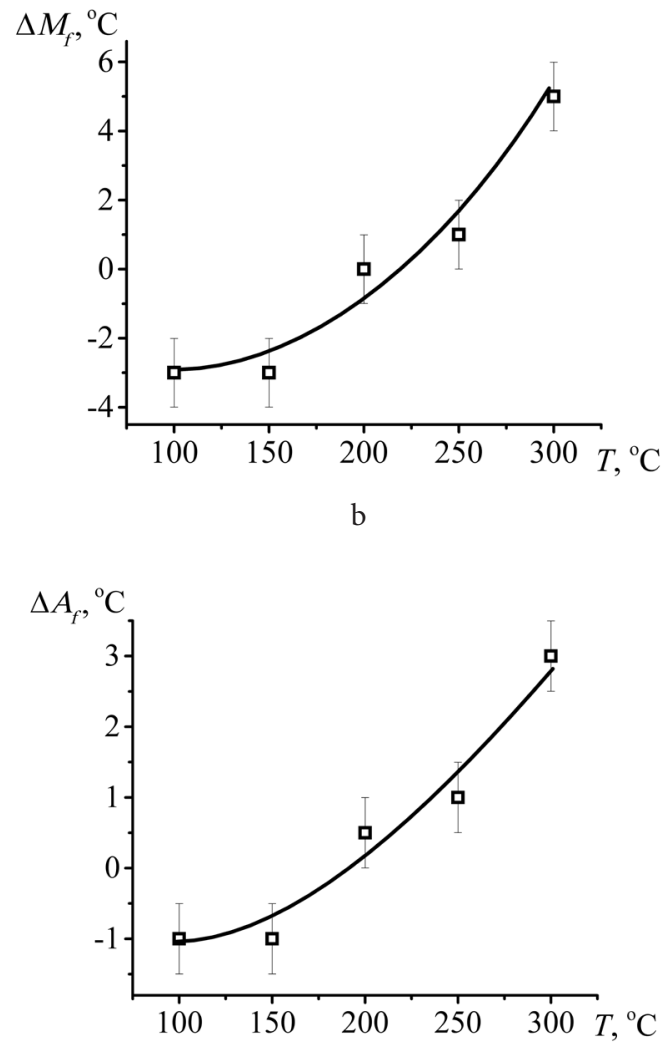

$\mathrm{d}$

Fig. 3. Influence of holding temperature $(t=60 \mathrm{~min})$ on $T_{\mathrm{B} 2-\mathrm{R}}(\mathrm{a}), M_{f}(\mathrm{~b}), A_{s}(\mathrm{c}), A_{f}(\mathrm{~d})$ transformations temperatures. 


\section{Discussion}

Therefore, the results of the study show that holding of the sample after the thermal cycles leads to an increase in the transformation temperatures, a decrease in the resistivity value and the height of the resistivity peak if the holding temperature is higher than the maximum temperature of the thermal cycle that was attained in the previous cycle. A decrease in the martensitic transformation temperatures and an increase in the resistivity during preliminary thermal cycles are caused by an increase in the dislocation density. Since dislocations appear during thermal cycling within the temperature range from 200 to $0^{\circ} \mathrm{C}$, then it is obvious that they are characterized by a stable configuration that does not change during heating up to $200^{\circ} \mathrm{C}$. In this case, holding at temperatures below $200^{\circ} \mathrm{C}$ does not influence the dislocation density and, as a result, the properties of the alloy do not change. Moreover, the temperature may decrease with further thermal cycling.

If the holding temperature is higher than $200^{\circ} \mathrm{C}$, then the dislocation configurations are not stable, and their change induces a partial recovery in the properties of the alloy. As a result, the martensitic transformation temperatures increase and the resistivity decreases. The higher the holding temperature, the more intensive a decrease in the dislocation density. As a result, the volume fraction of an alloy with a high dislocation density, which undergoes a B $\rightarrow$ R transformation, decreases, and the height of the peak on the $\rho(T)$ curve decreases. Therefore, the results of the study show that the intermediate holding of the equiatomic TiNi alloy after thermal cycles at temperatures higher than the maximum cycle temperature suppresses the influence of thermal cycling on the parameters of martensitic transformations.

\section{Conclusions}

1. The holding of the equiatomic TiNi alloy after thermal cycles at temperatures equal to the maximum cycle temperature or less does not lead to the recovery in the martensitic transformation temperatures.

2. Intermediate holding of the equiatomic TiNi alloy between thermal cycles at temperatures that are higher than the maximum cycle temperature suppresses the influence of thermal cycling on the parameters of martensitic transformations: temperatures and a sequence of martensitic transformations are restored. The higher the holding temperature, the more intensive the recovery in the properties of the alloy.

3. The distribution of dislocations that appeared during thermal cycles is stable at the maximum temperature of the cycle and may change if the temperature exceeds this value.

4. The intermediate holding of the equiatomic TiNi alloy between the thermal cycle at temperatures that exceed the maximum temperature of the cycle can be used to ensure a stable transformation temperature during thermal cycling.

Acknowledgements. The study was funded by RFBR, according to the research project No. 16-31-60043 mol_a_dk.

\section{References}

1. J. Mohd Jani, M. Leary, A. Subic, M.A. Gibson. Mater. Des. 56, 1078 (2014). DOI: 10.1016/j.matdes.2013.11.084

2. K. Otsuka, X. Ren. Intermetallics. 7, 511 (1999). DOI: 10.1016/S0966-9795(98)00070-3

3. [S. Miyazaki, Y. Igo, K. Otsuka. Acta Met. 34, 2045 (1986).

4. W. Tang, R. Sandström. Mater. Des. 14, 103 (1993). DOI: 10.1016/0261-3069(93)90003-E

5. Y. Furuya, Y.C. Park, Nondestr. Test. Eval. 8-9, 541 (1992). DOI: $10.1080 / 10589759208952731$

6. S. Belyaev, N. Resnina, A. Sibirev. J. Alloys Compd. 542, 37 (2012). DOI: 10.1016/j.jallcom.2012.07.082

7. S. Belyaev, N. Resnina, A. Sibirev. J. Mater. Eng. Perform. 23, 2339 (2014). DOI: 10.1007/s11665-014-0982-z

8. T. Simon, A. Kröger, C. Somsen, A. Dlouhy, G. Eggeler. Acta Mater. 58, 1850 (2010). DOI: $10.1016 /$ j.actamat.2009.11.028

9. A.J. C. Wilson. Acta Crystallogr. 17, 1090 (1964). DOI: $10.1107 / S 0365110 X 64004145$

10. A. Sibirev, S. Belyaev, N. Resnina. J. Alloys Compd. 661, 155 (2016). DOI: 10.1016/j.jallcom.2015.11.180

11. K.C. Atli, I. Karaman, R.D. Noebe, D. Gaydosh. Mater. Sci.Eng. A. 560, 653 (2013). DOI: 10.1016/j.msea.2012.10.009

12. S. Padula, S. Qiu, D. Gaydosh, R. Noebe, G. Bigelow, A. Garg, R. Vaidyanathan. Metall. Mater. Trans. A Phys. Metall. Mater. Sci. 43, 4610 (2012). DOI: 10.1007/s11661-012-1267-5

13. N. Resnina, S. Belyaev. J. Alloys Compd. 486, 304 (2009). DOI: $10.1016 /$ j.jallcom.2009.06.132

14. A. Sibirev, S. Belyaev, N. Resnina. Mater. Sci. Forum. 738-739, 372 (2013). DOI: 10.4028/www.scientific.net/MSF.738-739.372

15. K. Tanaka, T. Hayashi, Y. Itoh, H. Tobushi. Mech. Mater. 13, 207 (1992). DOI: 10.1016/0167-6636(92)90003-V

16. P.G. McCormick, Y. Liu. Acta Metall. Mater. 42, 2407 (1994). DOI: 10.1016/0956-7151(94)90319-0

17. J. Uchil, K.P. Mohanchandra, K.K. Mahesh, K.G. Kumara. Phys. B. 253, 83 (1998). DOI: 10.1016/s0921-4526(98)00378-0

18. J. Uchil, K. Mahesh, K.G. Kumara. Phys. B Condens. Matter. 324, 419 (2002). DOI: 10.1016/S0921-4526(02)01462-X

19. S. K. Wu, H.C. Lin, T.S. Chou. Acta Metall. Mater. 38, 95 (1990). DOI: 10.1016/0956-7151(90)90137-6

20. K. Otsuka, X. Ren. Prog. Mater. Sci. 50, 511 (2005). DOI: 10.1016/j.pmatsci.2004.10.001 